\title{
ИЗУЧЕНИЕ ЭФФЕКТИВНОСТИ ССК-77 ПРИ АНТРАЦИКЛИНОВОЙ КАРДИОМИОПАТИИ
}

\author{
А.П. Даниленко', К.С. Трунов², Л.М. Даниленко' \\ ${ }^{1}$ Белгородский государственный национальный исследовательский университет», \\ 308015, Российская Федерация, г. Белгород ул. Победы, 85. \\ ${ }^{2}$ Областное государственное бюджетное учреждение здравоохранения «Городская \\ больница №2»,308036, Российская Федерация, г. Белгорода ул. Губкина, д. 46.
}

DOI: 10.19163/MedChemRussia2021-2021-467

E-mail:1190540@bsu.edu.ru

Доксорубицин (DOX) является наиболее востребованным в онкологии антрациклиновым антибиотиком, однако для него характерно кардиотоксическое действие, что ограничивает его клиническую пользу у онкологических больных [1]. Для моделирования токсического повреждения миокарда крысам в/б в дозе 20 мг/кг вводили доксорубицин (ДОХ), через 48 часов проводили оценку показателей сократимости левого желудочка в условиях высокого ритма сокращений 480 ударов в минуту в течение 15 секунд на изолированном сердце крысы. В качестве дополнительного критерия оценки кардиопротекторного действия соединения ССК-77 (5-гидроксиникотината калия) использовали коэффициент $\mathrm{S}_{\text {tтт। }}$ (отражающий площадь динамики под кривой внутрижелудочкового давления), который в группе контроля (ДОХ)

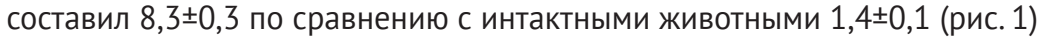

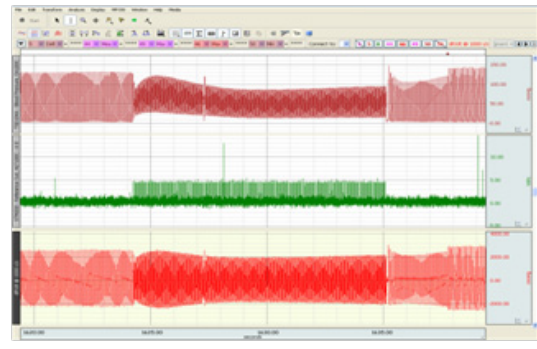

$A$

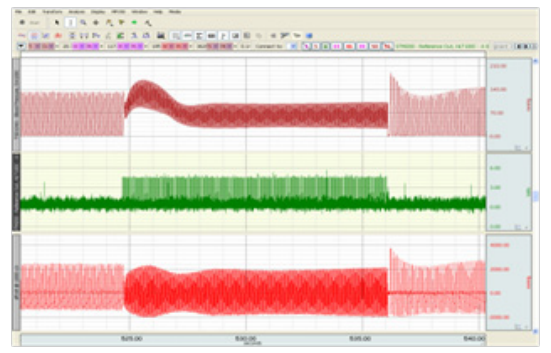

Б

Puс. 1. Нагрузочная проба с субмаксимальной электростимуляцией изолированного по Лангендорфу сердиа крысы. А - интактная группа; $Б$ - контроль.

Динамика давления в левом желудочке (мм. pm. ст.) с навязыванием сердиу учащенного ритма сокращений (480 уд/мин) в течение 15 сек.

В целом, нами показано, что предварительное введение ССК-77 (35 мг/ кг) обеспечивает защиту от повреждения, вызванного ДОХ. Эта выражалось в значительном снижении коэффициента $\mathrm{S}_{\mathrm{tTT}}$ до значений 3,3 .

\section{Литература}

[1] М. Г. Матяш, Т. Л. Кравчук, В. В. Высоцкая [и др.] // Индуцированная антрациклинами кардиотоксичность: механизмы развития и клинические проявления. Сибирский онкологический журнал. - 2008. - № 6. - С. 66-75.

$$
-467-
$$

